\title{
スターブ潤滑下におけるジャーナル軸受の静特性*
}

田浦 裕生 $^{* 1}$, 金子 覚 ${ }^{* 1}$

\section{Static Characteristics of Journal Bearings under Starved Lubricating Conditions}

\author{
Hiroo TAURA $^{* 1}$ and Satoru KANEKO \\ ${ }^{* 1}$ Nagaoka University of Technology, Dept. of Mechanical Engineering \\ 1603-1, Kamitomioka-cho, Nagaoka-shi, Niigata, 940-2188 Japan
}

\begin{abstract}
The static characteristics of journal bearings with an axial groove under starved lubrication are studied theoretically and a lubrication condition map is newly proposed. This map is represented using the contour map of the eccentricity ratio with the Sommerfeld number $S$ in the horizontal axis and the dimensionless oil flow rate $Q_{\text {sup }}$ externally supplied in the vertical axis for the wide range of the operating conditions. It is found from the map that the eccentricity ratio increases with the decrease of $Q_{\text {sup. }}$ This tendency is more marked for a higher Sommerfeld number. Journal center loci show that the attitude angle decreases with $Q_{\text {sup }}$. The degree of the starvation $\Lambda$ and the oil supply rate $\psi$ are defined as the ratio of the dimensionless oil flow rate into the inlet of the oil film region to that obtained under the flooded lubrication condition and as the ratio of $Q_{\text {sup }}$ to $Q_{\text {sup }} *$ obtained under flooded lubrication conditions, respectively. The degree of starvation $\Lambda$ varies with $\psi$ and the value of $\Lambda$ can be determined by setting the value of $\psi$. These facts suggest that the static characteristics and $\Lambda$ are theoretically predicted once the value of $Q_{\text {sup }}$ or $\psi$ is determined.
\end{abstract}

Key Words : Hydrodynamic Bearing, Lubrication, Journal Bearings, Oil Starvation, Static Characteristics, Starved Lubraication, Externally Supplied Oil-Flow Rate

\section{1. 緒}

油潤滑されるジャーナル軸受は，タービンやコンプレッサ等の産業用回転機械の軸に作用する半径方向荷重を 支持する軸受として広く使用されている．同軸受は，軸受面の一部に給油溝（もしくは給油孔）が設けられてお り，これらを通して外部よりしゅう動面に潤滑油が供給される．供給された潤滑油は，軸の回転方向に対して軸 受すきまが狭くなる部分で軸受油膜を形成し，軸と軸受とを分離する．この軸受油膜により，ジャーナル軸受は 低摩擦・長寿命といった優れた性能を発揮することを可能となっている．軸受油膜を形成する潤滑油は，ジャー ナルの回転や油膜圧力によって周方向に流れ，軸受すきま内を周方向に循環する流れを形成する. しかし，その うちの一部の潤滑油は軸方向にも流れ, 軸受端より外部に排出される. そのため, 定常運転時には, 軸受端より 外部へ排出される潤滑油の流量を，外部から絶えず供給することが求められる.

一般に油潤滑される軸受では, 油膜形成のみならず潤滑油による冷却効果を考慮して, 必要十分な量の潤滑油 が供給される. しかし, 給油能力の不足などにより, 十分な量の潤滑油が供給されない場合もしばしば存在する. 前者の状態はフラッド潤滑, 後者はスターブ潤滑と呼ばれる. フラッド潤滑の状態では, 与えられた運転条件に おいて最小油膜厚さを大きくすることができることから焼き付きに対する裕度が増加するなどの利点がある．し かし, 後者に比べてオイルホイップと呼ばれる軸受油膜に起因した回転軸の自励振動に対する安定限界速度が低 いことや, 近年の回転機械の大型化, 高速化に伴いフラッド潤滑を維持するために必要な給油量の増加により, 給油設備が大型化・高コスト化するなどの問題がある. これらの問題を解決するため, 適切な最小油膜厚さの確 保をした上で，給油量を減少させた状態，つまりスターブ潤滑下で適切に運転されることが求められている.

\footnotetext{
* 原稿受付 2011 年 5 月 26 日

*1 正員, 長岡技術科学大学 工学部（广940-2188 新潟県長岡市上富岡町 1603-1）

E-mail: htaura@mech.nagaokaut.ac.jp
} 
スターブ潤滑下におけるジャーナル軸受の軸受性能に関するこれまでの研究は，スターブ潤滑下における油膜

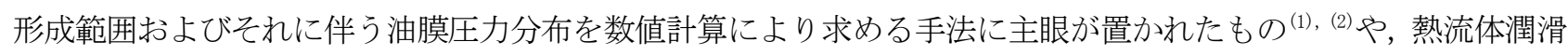
理論を適用してスターブ潤滑下の軸受特性について定性的な傾向を報告しているもの ${ }^{(3),(4)}$, 実験的に給油量を減 少させた状態での軸受特性の測定や油膜形成範囲の可視化が実施されているもの ${ }^{(5)}{ }^{(6)}$ ，また，近年ではジャーナ ル軸受で支持された回転軸の安定化を目的としてスターブ潤滑を適用した場合の振動特性を数值計算と実験の両 面から検討したもの (7), (8) などがある. 以上のいずれの研究においても, ジャーナル軸受の潤滑特性は油量不足の 程度により変化することが示されている. それらの結果の整理では, 有次元の給油量 ${ }^{(4)}$ ( $(8)$ または, 軸受油膜が形 成されている領域の前端から流入する無次元流量 ${ }^{(2),(3)}$ を, 油量不足の程度を表す指標として用いている. 軸受設 計の立場でこれらの指標を考えると, 前者は, フラッド潤滑状態を維持するための給油量が軸受寸法, 軸回転速 度などの運転条件によって異なるため, 結果を直接使用するのが難しいなどの問題がある. 一方, 後者は, 物理 的な意味合いから油量不足の状態を評価するのには適当な指標と考えられるが，その結果を利用するには，与え られた給油量から, その指標の值, つまり, 軸受油膜前端に流入する無次元流量を数值計算により求め, 得られ た值を用いてスターブ潤滑下の特性を求めることが必要となり, 計算手順が多いなどの問題がある. これらの点 を踏まえると，設計時に与える軸受形状（軸直径や軸受幅，すきま）と運転条件（荷重，軸回転速度，潤滑油の 粘性係数）によって定まる無次元給油量を用いて，これとスターブ潤滑下の軸受特性との関係が直接求められる ことが望まれるが，このような研究は著者らが知る範囲ではこれまで行われていない.

そこで本研究では，軸受幅径比（LID）が 1 の軸方向油溝付き真円ジャーナル軸受を対象として，フラッド潤 滑状態とスターブ潤滑状態の幅広い運転条件における軸受静特性（運転条件と偏心率, 偏心角との関係）を数值 解析により調べ, その結果を無次元給油量を用いて整理した. さらに, 無次元給油量と油量不足の程度（スター ブ度）との関係を明らかにしたので，その結果も併せて報告する.

\section{2. 解析モデルと解析方法}

図 1 に本研究で使用した解析モデルを示寸. 対象とした軸受は, 軸方向給油溝が鉛直上方に一力所取り付けら れた真円ジャーナル軸受である. 軸受の仕様は, 軸受内径を $D(=2 R)$, 軸受幅を $L$, 軸受平均半径すきまを $C$, 荷重を $W$ である。 $L / D$ は 1 とした。潤滑油は軸受幅中央の外周部に設けた円孔より供給され，さらに軸受幅方 向の給油溝を介してすきま内に流入する. 給油溝は溝角度 $\theta_{\mathrm{g}}$ (本研究では $10^{\circ}$ とした) で荷重方向に対して対称 に配置されており, 軸方向には軸受幅全体にわたって設けられている. ジャーナルは, 軸受中心 $\mathrm{O}_{\mathrm{b}}$ から偏心量 $e$, 偏心角 $\phi$ だけ偏心した位置 $\mathrm{O}_{\mathrm{j}}$ を中心として, 角速度 $\omega$ で回転している. 軸受中心 $\mathrm{O}_{\mathrm{b}}$ を原点に, 荷重方向に $x$ 軸,
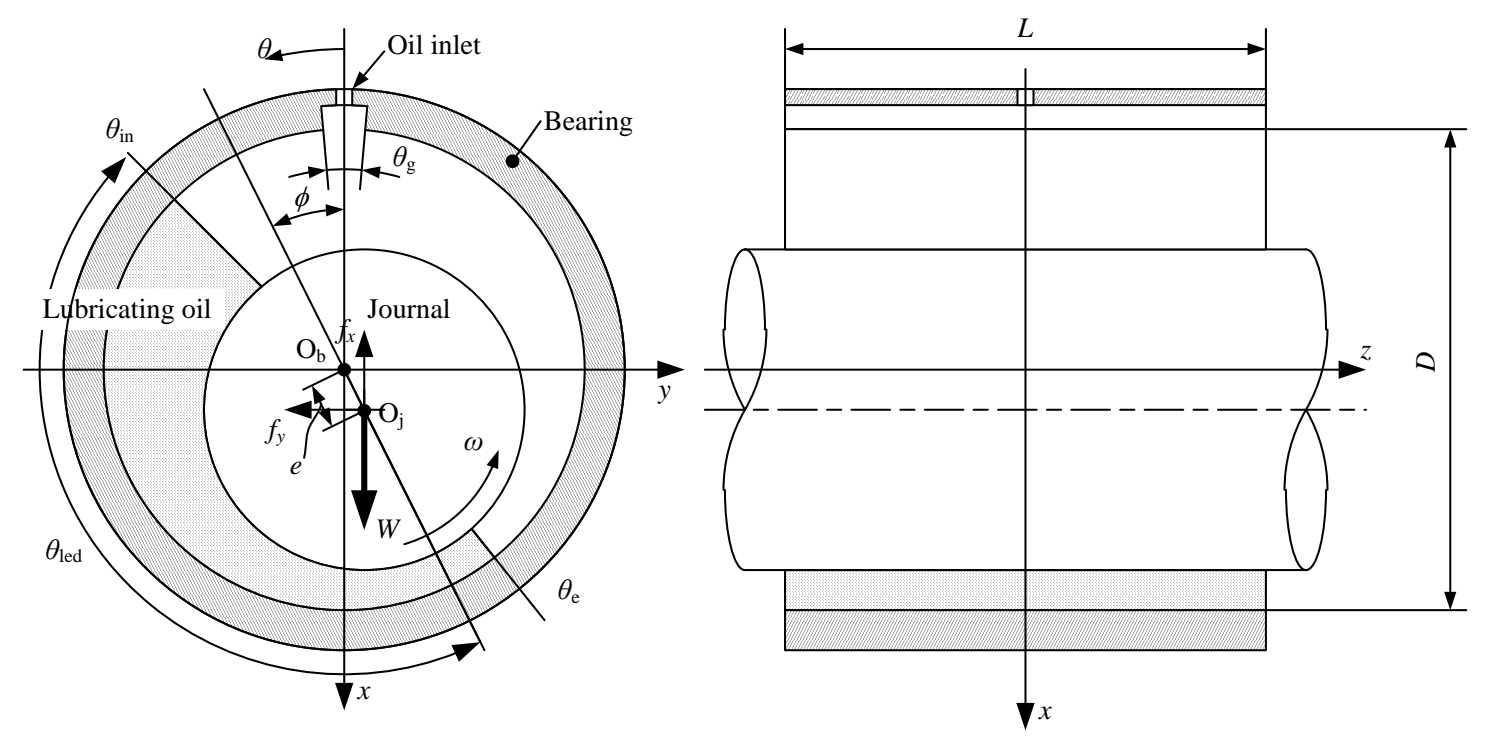

Fig. 1 A schematic of the theoretical model 
軸方向に $z$ 軸, 回転面内において $x$ 軸に垂直な方向に $y$ 軸, また, $x$ 軸の鉛直上方より円周方向座標 $\theta$ を定義する. 軸の回転により軸受面に形成される軸受油膜で発生する油膜圧力 $p$ は, 潤滑油の粘性係数を $\eta$ とすると, 次式で

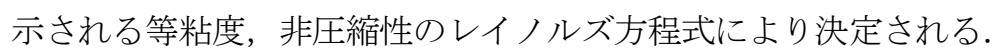

$$
\frac{1}{R^{2}} \frac{\partial}{\partial \theta}\left\{h^{3} \frac{\partial p}{\partial \theta}\right\}+\frac{1}{(L / D)^{2}} \frac{\partial}{\partial z}\left\{h^{3} \frac{\partial p}{\partial z}\right\}=6 \eta R \omega \frac{\partial h}{\partial \theta}
$$

式(1)中の $h$ は油膜厚さであり, 偏心率 $\varepsilon(=e / C)$ を用いると次式で与えられる.

$$
h=C(1+\varepsilon \cos (\theta-\phi))
$$

式(1)より圧力分布を求めるためには, 形成される油膜の周囲における圧力の境界条件を定める必要がある. 図 2 に, 油膜形成範囲の模式図を示す. スターブ潤滑下では給油溝を介して外部から油膜前端へ供給される給油量 $q_{\text {sup }}$ により油膜開始角度 $\theta_{\text {in }}$ が変化するため, 圧力の境界条件を設定する際にはあらかじめ, $\theta_{\text {in }}$ を決定しなくてはな らない. 本研究では, $\theta_{\text {in }}$ の決定に際し, 次にように仮定した。

- 油膜開始角度 $\theta_{\text {in }}$ は軸方向に一定である

- 外部からの給油量 $q_{\text {sup }}$ は, 軸受端からの排出量 $q_{\mathrm{s}}$ に等しい

- 油膜後端より周方向に流出する潤滑油流量 $q_{\mathrm{r}}$ は全て, 再度油膜入り口に戻る（再循環する）

・ 給油圧力はゼロである

$\theta_{\text {in }}$ の決定の手順では, はじめに, 運転条件（荷重 $W$, 軸回転速度 $N$, 粘性係数 $\eta$ など）および $q_{\text {sup }}$ を与えて, 偏心率 $\varepsilon$, 偏心角 $\phi$ に適当な初期值を設定する. 油膜開始角度 $\theta_{\text {in }}$ に適当な初期值を与えて, $\theta=\theta_{\text {in }}$ の位置の圧力 をゼロとして圧力分布を求める. これ以外の境界条件は, 軸受端で圧力がゼロ, 油膜後端の境界条件はレイノル ズの境界条件を適用する. 式(1)をコントロールボリューム法により離散值化し, 加速緩和法により収束計算する ことで, 油膜圧力分布が数值的に求められる. 得られた油膜圧力分布より, 軸受両端から流出する潤滑油の流量 $q_{\mathrm{s}}$ が, 次式により求められる.

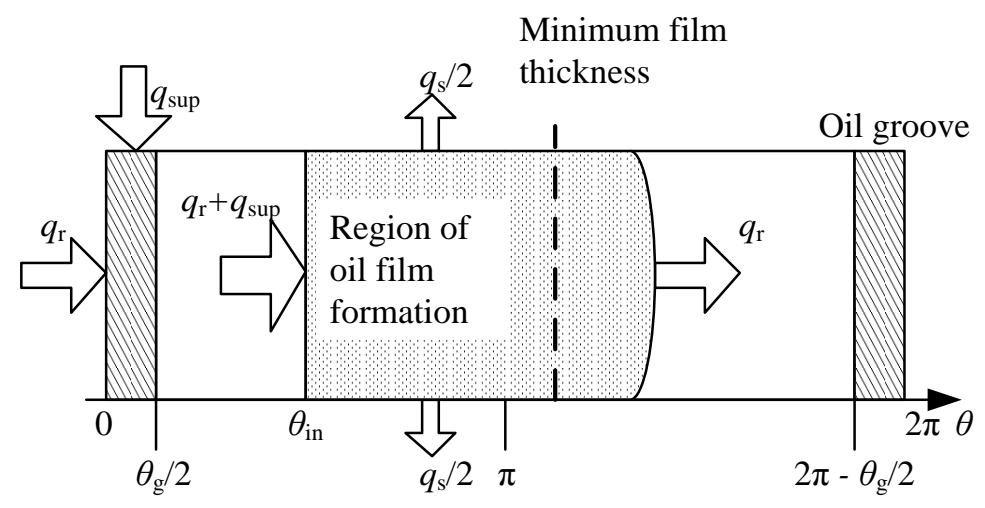

Fig. 2 oil flow and the region of oil film formation

$\phi<\theta_{g} / 2$

$\phi>\theta_{\mathrm{g}} / 2$
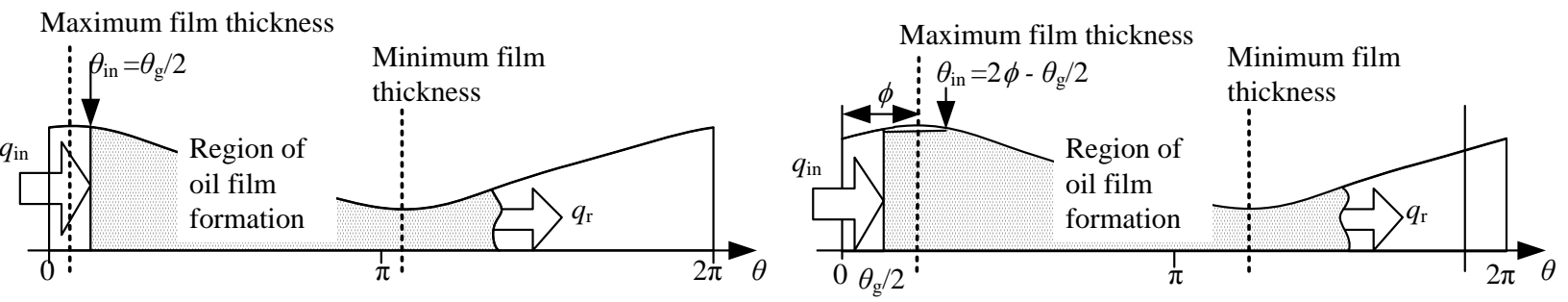

Fig. 3 Schematics of the region of oil film formation 


$$
q_{s}=-\left.2 \int_{0}^{2 \pi} \frac{h^{3}}{12 \eta} \frac{\partial p}{\partial z}\right|_{z=L / 2} \operatorname{Rd} \theta
$$

$q_{\mathrm{s}}$ と給油量 $q_{\text {sup }}$ とを比較し, $q_{\mathrm{s}}<q_{\text {sup }}$ の場合には軸受端からの潤滑油の流出量が少ないのでこれを増加させるため に $\theta_{\text {in }}$ を減少し， $q_{\mathrm{s}}>q_{\mathrm{sup}}$ であれば逆に $\theta_{\mathrm{in}}$ を増加させ，再度油膜圧力分布を求める，この操作を最終的に $q_{\mathrm{s}}=q_{\mathrm{sup}}$ となるまで繰り返すことで $\theta_{\text {in }}$ を決定する.

なお，本研究では $\theta_{\mathrm{in}}$ の下限值（最小值）を，図 3 に示すように， $\phi<\theta_{\mathrm{g}} / 2$ の範囲では $\theta_{\mathrm{g}} / 2 ， \phi>\theta_{\mathrm{g}} / 2$ の範囲では $2 \phi-\theta_{\mathrm{g}} / 2$ とした. 前者の $\theta_{\mathrm{g}} / 2$ は給油溝後端の円周方向角度でありしゅう動面の開始角度に対応している. これに 対し後者では, 給油溝直後の軸受すきまは回転方向に対して先広がりであるため, 給油溝直後の流量ではすきま 内を潤滑油で満たすことができず，油膜が形成されない。したがって， $\phi=\theta_{\mathrm{g}} / 2$ とすきま厚さが等しくなるまで の範囲, つまり, $\theta_{\mathrm{g}} / 2<\theta<2 \phi-\theta_{\mathrm{g}} / 2$ までは, 流量一定で圧力は大気圧となる. そして $\theta=2 \phi-\theta_{\mathrm{g}} / 2$ でようやくすき まが潤滑油で満たされ油膜が形成される。これより， $\phi>\theta_{\mathrm{g}} / 2$ の範囲では $\theta_{\mathrm{in}}=2 \phi-\theta_{\mathrm{g}} / 2$ として計算を行った.

また， $\theta_{\text {in }}$ を記の最小值に設定した場合に求められる $q_{\mathrm{s}}$ は，その運転状態において軸受すきま内から排出され る最大の流量 $q_{\mathrm{s} \text { max }}$ であり, 軸受すきま内に供給できる最大の給油量 $q_{\text {sup }}^{*}$ と等しくなる $\left(q_{\mathrm{sup}}^{*}=q_{\mathrm{s} \max }\right)$. したがって, 給油量 $q_{\text {sup }}$ が $q_{\text {sup }}^{*}$ を超える場合には, $\Delta q_{\text {sup }}=q_{\text {sup }}-q_{\text {sup }}^{*}$ が余剰流量として, 軸方向給油溝から軸受外部に直ちに流 出されることになる. 本研究では, 給油量 $q_{\text {sup }}$ が $q_{\text {sup }}^{*}$ 以上の場合をフラッド潤滑状態, $q_{\text {sup }}^{*}$ 未満の場合をスター ブ潤滑状態と定義した.

上記の方法により $\theta_{\text {in }}$ が決定すると, 同時に圧力分布も得られる. それを軸受面全体で積分することにより油膜 反力が求められる. 油膜反力の $x$ 方向成分 $f_{x}, y$ 方向成分 $f_{y}$ はそれぞれ次式で求められる.

$$
\begin{gathered}
f_{x}=-\int_{-L / 2}^{L / 2} \int_{0}^{2 \pi} p \cos \theta R \mathrm{~d} \theta \mathrm{d} z \\
f_{y}=-\int_{-L / 2}^{L / 2} \int_{0}^{2 \pi} p \sin \theta R \mathrm{~d} \theta \mathrm{d} z
\end{gathered}
$$

得られた $f_{y}$ がゼロとなるように，繰り返し計算により $\phi$ の值を求める．なお， $f_{y}$ を変化させた場合には，上記 の方法により $\theta_{\text {in }}$ 再度求める.その後, さらに負荷荷重と $f_{x}$ が釣り合うように $\varepsilon$ を繰り返し計算で求めることで, ジャーナルの静的平衡点が求められる.

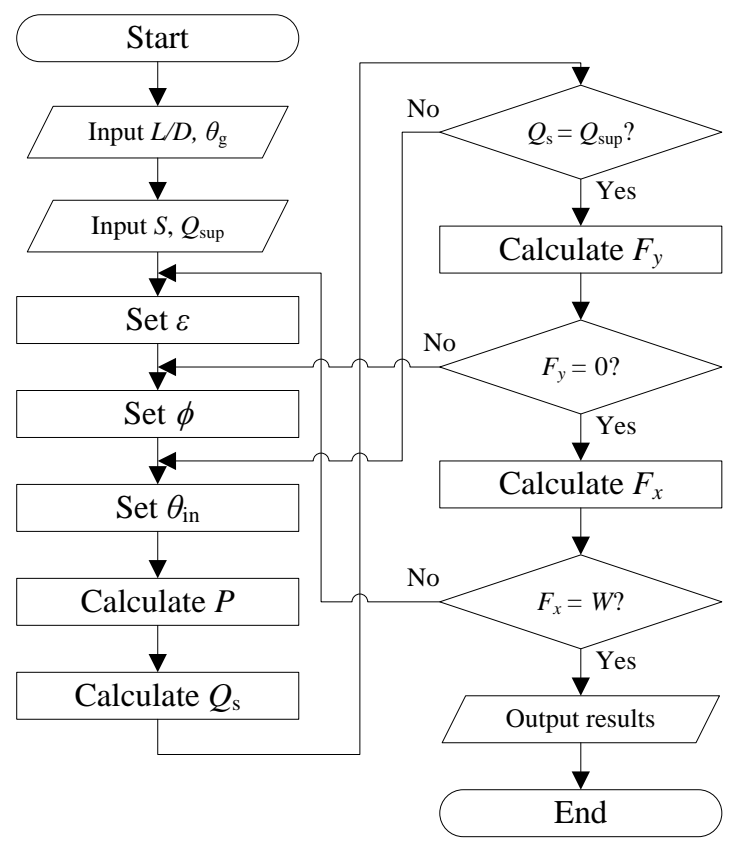

Fig. 4 Flowchart of the numerical calculation of the bearing characteristics considering externally supplied oil-flow rate 
本研究では，式(6)に示す無次元変数を用いて，式(7)〜(11)に示す無次元化式を用いて解析を行った.

$$
\begin{aligned}
H=h / C, \quad Z=z /(L / 2), \quad P & =p C^{2} /\left(\eta \omega R^{2}\right), \quad Q=q /(C L R \omega), \quad F=f C^{2} /\left(\eta \omega R^{2}\right) \\
\frac{\partial}{\partial \theta}\left\{H^{3} \frac{\partial P}{\partial \theta}\right\} & +\frac{1}{(L / D)^{2}} \frac{\partial}{\partial Z}\left\{H^{3} \frac{\partial P}{\partial Z}\right\}=6 \frac{\partial H}{\partial \theta} \\
H & =1+\varepsilon \cos (\theta-\phi) \\
Q_{\mathrm{s}} & =-2 \int_{0}^{2 \pi} \frac{H^{3}}{12} \frac{\partial P}{\partial Z} \mathrm{~d} \theta \\
F_{x} & =-\int_{-1}^{1} \int_{0}^{2 \pi} P \cos \theta \mathrm{d} \theta \mathrm{d} Z \\
F_{y} & =-\int_{-1}^{1} \int_{0}^{2 \pi} P \sin \theta \mathrm{d} \theta \mathrm{d} Z
\end{aligned}
$$

また，次式で定義されるゾンマーフェルト数 $S$ により運転状態を整理した.

$$
S=\frac{\eta D L N}{W}\left(\frac{R}{C}\right)^{2}
$$

以上の手順をまとめたフローチャートを図 4 に示す.

\section{3. 解析結果および考察}

\section{$3 \cdot 1$ 給油量が軸受静特性に及ぼす影響}

図 5 に，ジャーナル軸受の運転状態を示寸図（軸受状態図）を示寸，同図は，スターブ潤滑下におけるジャー ナル軸受の運転条件を決定する二つの量, ゾンマーフェルト数 $S$ と無次元給油量 $Q_{\text {sup }}$ を与えて, そのときに求め られる偏心率 $\varepsilon$ 等高線図である. 横軸は $S$, 縦軸は $Q_{\text {sup }}$ で, 両軸とも対数軸で表示している. 図中の点線はフ ラッド潤滑とスターブ潤滑との境界を示しており, 点線よりも上側の領域がフラッド潤滑領域, 下側がスターブ 潤滑領域である，点線で示したフラッド潤滑とスターブ潤滑の境界上の值 $Q_{\text {sup }}^{*}$ は，供給した潤滑油がすべて軸受 寸きま内部に入る最大值である， $Q_{\text {sup }}^{*}$ は， $S$ の増加に伴い減少しているが，これは $\varepsilon$ が減少することで油膜圧力 の最大值が低下した結果, 軸方向の圧力勾配が減少し, 軸受端から漏れる無次元流量 $Q_{\mathrm{s}}\left(=Q_{\text {sup }}\right)$ が減少したため と考えられる. 点線より上側のフラッド潤滑領域では， $Q_{\text {sup }}$ を増加させても， $Q_{\text {sup }}^{*}$ 以上潤滑油が軸受すきま内部

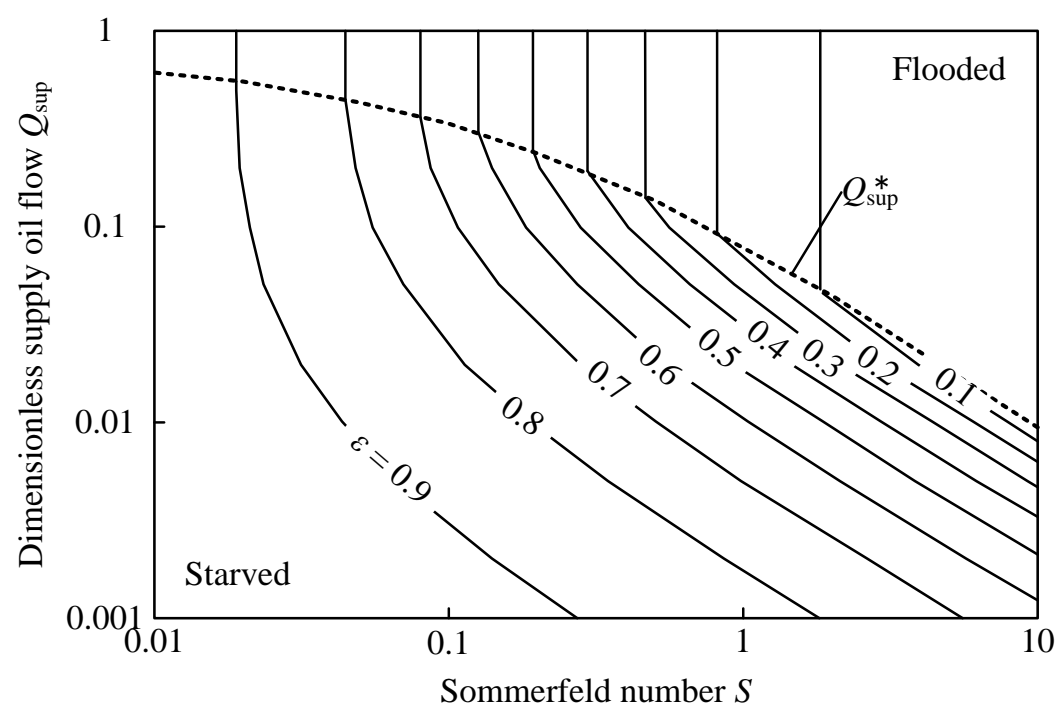

Fig. 5 Dimensionless lubrication condition map $(L / D=1)$ 
Table 1 the operating condition used in the calculation

\begin{tabular}{c|c}
\hline Journal diameter $D(=2 R)$ & $100 \mathrm{~mm}$ \\
\hline Bearing width $L$ & $100 \mathrm{~mm}$ \\
\hline Shaft Speed $N(=\omega /(2 \pi))$ & varies with $S$ \\
\hline Radial clearance $C$ & $0.05 \mathrm{~mm}$ \\
\hline Viscosity of lubricating oil $\eta$ & $10 \mathrm{mPa} \cdot \mathrm{s}$ \\
\hline Applied Load $W$ & $1000 \mathrm{~N}$ \\
\hline
\end{tabular}

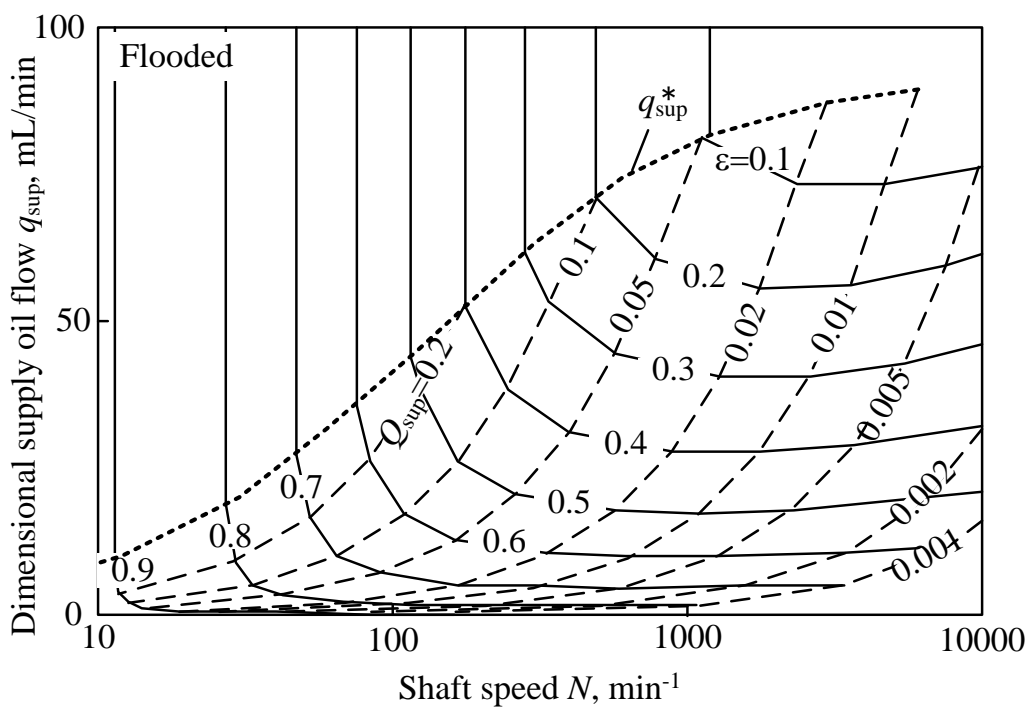

Fig. 6 An example of dimensional lubrication condition map

に入っていかない，そのため， $Q_{\text {sup }}$ を増加させても油膜に流入する流量が一定となり油膜形成範囲が変化しなく なる. 寸なわち, $Q_{\text {sup }}>Q_{\text {sup }}^{*}$ の条件では, $S$ 一定の下で $Q_{\text {sup }}$ を増加させても $\varepsilon$ は減少せず一定となるため, 図中の 点線以上の $Q_{\text {sup }}$ では等高線が真上に伸びることになる，一方，点線より下側のスターブ潤滑領域では， $S$ が一定 である場合， $Q_{\text {sup }}$ を低下させると $ょ$ が増加する. この原因を考えると， $Q_{\text {sup }}$ の低下により油膜の形成範囲が縮小寸 る. 縮小した油膜形成範囲で同じ油膜反力を発生させるためには, 最小寸きまを減少させる, つまり $\varepsilon$ を増加さ せる必要があるためだと考えられる. また, $S$ が増加するにつれて, $Q_{\text {sup }}$ の低下に伴う $\varepsilon$ の変化量が大きくなる. これは, $S$ が小さな場合は, $\varepsilon$ が既に大きな值であるため, $Q_{\text {sup }}$ 䓜下しても $\varepsilon$ をさらに増加させる余地が小さい が， $S$ が大きい場合は $Q_{\text {sup }}$ の低下にともない $\varepsilon$ を大きく増加させる余地が大きいためと考えられる.

上記の結果では, 軸回転速度 $N$ によって増加する傾向を持つ $S$ が大きな場合ほど, フラッド潤滑となるために 必要な $Q_{\text {sup }}^{*}$ が低下している，これは一見すると， $N$ が高いほど，フラッド潤滑に必要となる量が減少するように も思われ, 従来の知見と異なる結果 ${ }^{(6)}$ に見える. しかし, 式(6)の $Q_{\text {sup }}$ の定義では， $q_{\text {sup }}$ を軸回転角速度 $\omega て ゙$ 除し ているため， $Q_{\text {sup }}$ における $\omega$ の影響を取り除いて考えなくてはならない. これには有次元の給油量 $q_{\text {sup }}$ により評 価すること必要がある．そこで，図 5 の軸受状態図に対して，ある特定の条件を設定し有次元化して考える．表 1 に設定した条件を示す． $S$ の変化は $N$ の変化にのみよって引き起こされるとした．なお，表 1 以外の条件であ っても以下に示寸定性的な傾向は基本的に変化しない. 図 6 亿結果を示寸. 縦軸は $q_{\text {sup }}$, 横軸は $N$ である. 実線 は $\varepsilon$, 破線は $Q_{\text {sup }}$, 点線はフラッド潤滑とスターブ潤滑の境界となる有次元の給油量 $q_{\text {sup }}^{*}$ を示している. 有次元化 した結果， $q_{\text {sup }}^{*}$ は $N$ に伴い常に増加しており, 従来の知見と一致するものとなっている. また, 同図より, $q_{\text {sup }}$ を一定として軸回転速度を変化させると, 低軸回転速度ではフラッド潤滑下で運転できたものが, ある軸回転速 度以上でスターブ潤滑に変化することが分かる.この軸回転速度は， $q_{\text {sup }}$ を増加させると増加することが分かる.

図 6 中のスターブ潤滑領域を見ると， $q_{\mathrm{sup}}$ 一定で $N$ を増加させていくと， $\varepsilon$ はフラッド閏滑領域では減少してい たものが，スターブ潤滑領域に入ると変化が小さくなり，Nの大きい領域では逆に $N$ とともに増加する傾向が見 
られる.このため, $q_{\text {sup }}$ を一定として $N$ を増加させる場合, $N$ をじんなに増加させても $\varepsilon$ をある值以下にするこ とができない，つまり $\varepsilon$ には下限值が存在することが分かる．これは， $q_{\mathrm{sup}}$ 一定の条件で $N$ を増加させると，無 次元給油量 $Q_{\text {sup }}$ が低下寸るため, $N$ が高い程より厳しい条件で運転されることになるためと考えられる．また， この結果を見ると，スターブ潤滑領域の内部では $\varepsilon$ の変化は比較的小さいことから，適切な運転条件を設定すれ ば, 比較的広い軸回転速度の範囲で十分な厚さの最小油膜厚さを確保できることが分かる. 例えば $q_{\mathrm{sup}}=30 \mathrm{~mL} / \mathrm{min}$

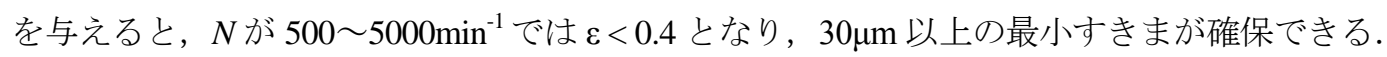

続いてスターブ潤滑下におけるジャーナル中心位置の変化を考える. 図 7 に， $Q_{\text {sup }}$ をパラメータとして，各 $\varepsilon$ における静的平衡状態にあるジャーナル中心位置をつないで作成した軸心軌跡を示す．ジャーナルの回転方向は 反時計回りである. 図中の最も右側の曲線が $Q_{\text {sup }} \geqq Q_{\text {sup }}^{*}$ のフラッド潤滑の結果であり， $Q_{\text {sup }}$ の值に依らず軸心軌 跡が $Q_{\text {sup }}^{*}$ の場合と同じ曲線で表される．一方，スターブ潤滑下（ $\left.Q_{\text {sup }}<Q_{\text {sup }}^{*}\right)$ では， $Q_{\text {sup }}$ により異なる軸心軌跡を とっている．これらの軸心軌跡を見ると， $\varepsilon$ が低い場合にはフラッド潤滑の軸心軌跡と一致しているが，ある值

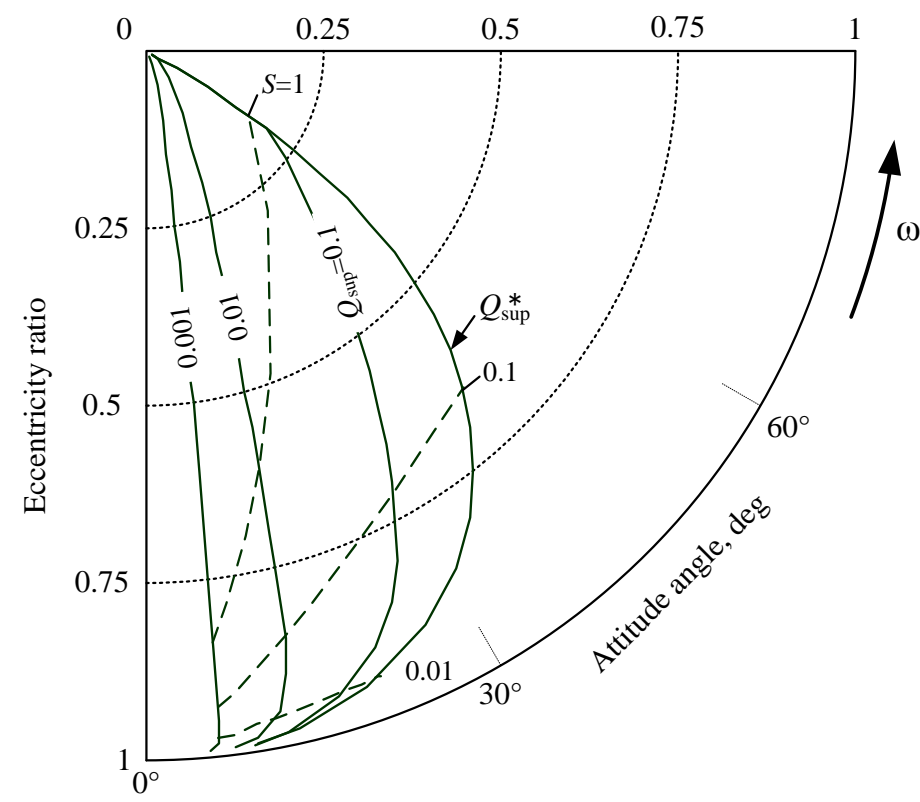

Fig. 7 Journal center loci for various values of dimensionless supply oil flow rate and Sommerfeld number $(L / D=1)$

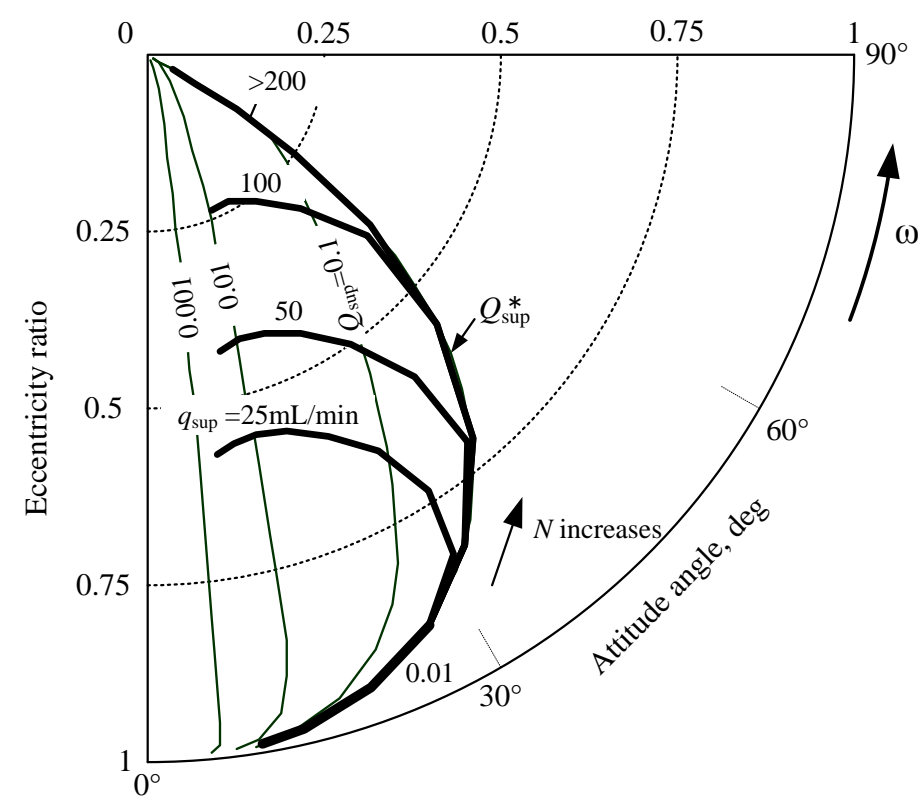

Fig. 8 Journal center loci for various values of dimensional supply oil flow rate $(L / D=1)$ 
以上になると分岐して $\phi$ が小さい別の曲線になる. 分岐する際の $\varepsilon$ の值は, $Q_{\text {sup }}$ が大きなものほど大きい. この図 より，スターブ潤滑下の特徵として， $Q_{\text {sup }}$ が低下寸るにつれて， $\phi$ が減少することが挙げられる．この原因を考 えると, スターブ潤滑状態では, 狭い油膜形成範囲で荷重を支持するために $\varepsilon$ が増加する. この際, 単に $\varepsilon$ を増 加させただけでは，y 方向の油膜反力をゼロとする静的平衡条件を満足させることができないため, 形成される 油膜範囲を荷重方向に集中させ, $y$ 方向の油膜反力をゼロにすることが求められる. このため, 軸受すきまの狭 い部分を荷重方向に近づける，つまり $\phi$ を減少させることが必要になったと考えられる.

また，図 7 中の破線は，S一定とした場合のジャーナル中心の軌跡である. これは $W, N$ 等の運転条件を固定 した状態で, 無次元給油量 $Q_{\text {sup }}$ のみ変化させた場合のジャーナル中心の軌跡を示している．S一定で $Q_{\text {sup }}$ 減 少させると, 軸心は破線に沿って移動するので, $S=1$ の場合には, 軸心はほぼ真下に向かい大きく変化し, $S=0.1$ の場合には $x$ 軸に対して約 $45^{\circ}$ の角度で左下に, さらに $S$ が小さい $S=0.01$ の場合には、ジャーナル中心はやや左 下向きに移動するなど， $S$ の值によって無次元給油量の変化にともなうジャーナル中心の軌跡は大きく異なるこ とが分かる.

図 8 に, 有次元の給油量 $q_{\text {sup }}$ を一定として, 軸回転速度 $N$ を変化させた場合における軸心軌跡を示す. 同図は, 図 7 と同様に, 表 1 の条件で計算したものである. 給油量が最小の $25 \mathrm{~mL} / \mathrm{min}$ の結果に着目すると, $\varepsilon$ が大きい低 軸回転速度の場合には，フラッド潤滑の場合の軸心軌跡と一致する. しかし， $N$ が増加して $\varepsilon$ が約 0.8 以下にな ると分岐し， $N$ の増加とともに反時計回りの軌跡を描くようになる.これは $q_{\text {sup }}$ 一定でも $N$ の増加に伴い $Q_{\text {sup }}$ が 減少し, 図 7 に示寸ように $\phi$ が減少寸るためである. 給油量が $100 \mathrm{~mL} / \mathrm{min}$ 以下では, 定性的に同様な結果が得ら れており， $q_{\text {sup }}$ の増加により，フラッド潤滑のジャーナル中心軌跡から分岐する $\varepsilon$ の值が低下している. 以上に 示した傾向は, Tanaka ${ }^{(5)}$ の実験結果と一致するものである. 一方， $q_{\text {sup }}$ を $200 \mathrm{~mL} / \mathrm{min}$ 以上の結果では， $\varepsilon$ が 0 近傍 までフラッド潤滑時のジャーナル中心軌跡に沿って変化しており, スターブ潤滑になっていないことが分かる. これは図 6 の結果と対応するものである.

\section{$3 \cdot 2$ 給油量と軸受油膜に流入する潤滑油流量の関係}

上記結果の整理に用いた無次元給油量 $Q_{\text {sup }}$ と, スターブ状態の度合い, つまり，軸受油膜の油量不足の程度と の関係について考える. 図 2 より, 軸受油膜前端 $\left(\theta=\theta_{\text {in }}\right)$ に流入する潤滑油の周方向無次元流量 $Q_{\text {in }}$ は, $Q_{\text {sup }}$ と 油膜後端から周方向へ流出する無次元流量（再循環量） $Q_{\mathrm{r}}$ の和で与えられる. 油膜前端よりも上流側では圧力が 発生しないため, この領域における潤滑油の流れは，周方向へのクエット流れのみとなる．このときの周方向平

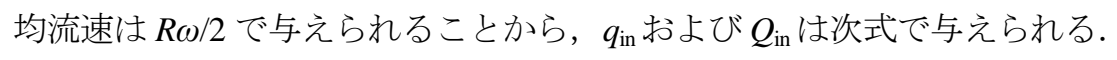

$$
\begin{gathered}
q=\frac{R \omega}{2} h L=\frac{H}{2} C L R \omega \\
Q_{\text {in }}=\frac{H}{2}
\end{gathered}
$$

式(14)より， $Q_{\text {in }}$ は形成される軸受油膜前端の無次元油膜厚さに直接関連した值であり， $Q_{\text {in }}$ が大きな程，油膜前縁 の油膜は厚く，さらに同一偏心率であれば，油膜形成範囲も大きくなることが分かる．これから，スターブ状態 の度合いは $Q_{\text {sup }}$ よりも, 油膜形成範囲を直接支配する因子である $Q_{\text {in }}$ より評価するのが適当と考え, 本研究で はスターブ度 $\Lambda$ を次式のように定義する.

$$
\Lambda=\frac{Q_{i n}}{Q_{i n}^{*}}
$$

ここで， $Q_{\mathrm{in}}^{*}$ はフラッド潤滑状態 $\left(\theta_{\mathrm{in}}\right.$ の最小值 $)$ における $Q_{\mathrm{in}}$ の值である. $\Lambda$ は，0から 1 の值をとり， 1 の場合 はフラッド潤滑状態，０の場合は油膜が形成されない状態に対応する. $\Lambda$ が小さくなるほど軸受油膜に流入する 潤滑油量が小さいため, より厳しい状態で運転されることを意味する.

図 9 に $\Lambda$ と油膜形成範囲の関係を示す. 図の縦軸は, 軸受油膜前端から最小油膜厚さ位置までの周方向角度 $\theta_{\mathrm{led}}$ である.いずれの $S$ の場合も， $\Lambda$ の低下により $\theta_{\mathrm{led}}$ は減少している，つまり油膜形成範囲が減少していることが 分かる. また， $\Lambda$ が一定のもとでは， $S$ が小さなものほど $\theta_{\mathrm{led}}$ は小さい值をとる. 


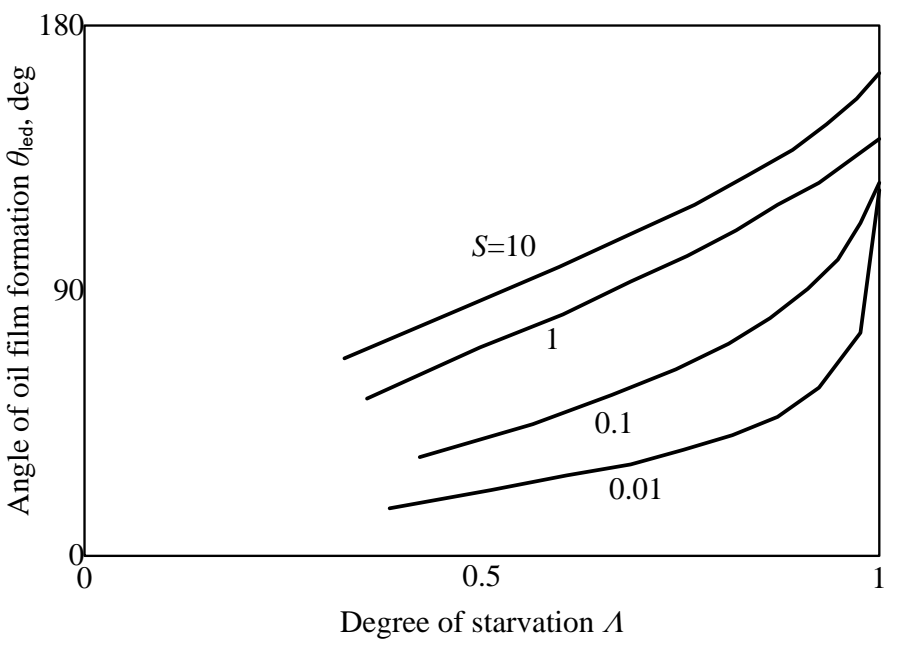

Fig. 9 Relationship between angle of oil film formation $\theta_{\text {led }}$ and degree of starvation $\Lambda$ for various values of $S(L / D=1)$

図 10 に, フラッド潤滑時における $Q_{\mathrm{in}}$ と $Q_{\text {sup }}$ および $Q_{\mathrm{r}}$ の関係を示す．図中の $Q_{\mathrm{r}}^{*}$ は $Q_{\text {sup }}^{*}$ が流入した際の再循環 量を表す. $S$ が低い場合には， $Q_{\text {sup }}^{*}$ は $Q_{\mathrm{r}}^{*}$ に比べて大きな值をとる.これは， $S$ が小さい場合には $\varepsilon$ が大きいため 油膜圧力の最大值が増加し, 軸受端からの漏れ流量 $Q_{s}^{*}\left(=Q_{\text {sup }}^{*}\right)$ が増大したためと考えられる. しかし， $S$ が増 加するに従い $\varepsilon$ が減少するため, $Q_{\text {sup }}^{*}$ は低下していき, $S>1$ では非常に小さな值となる．その結果， $S$ が大きな 場合には $Q_{\mathrm{r}}^{*}$ の方が大きな割合を占めるようになる．また， $Q_{\mathrm{in}}^{*}$ は，Sの増加により減少する傾向が見られる. 同 図を見ると, $S$ が小さな場合には $Q_{\text {sup }}$ を減少させることで $Q_{\text {in }}$ を変化させられることは明らかである一方, $S$ が大 きな場合には， $Q_{\text {in }}$ 占める $Q_{\text {sup }}$ の割合が非常に小さいため, $Q_{\text {in }}$ を変化させる余地がないように考えられる.

ここで，外部から供給される給油量の定量的指標として給油率 $\psi$ を，次式のように定義する.

$$
\psi=\frac{Q_{\text {sup }}}{Q_{\text {sup }}^{*}}
$$

給油率 $\psi$ をパラメータとして， $Q_{\text {sup }}, Q_{\text {in }}$ および $Q_{\mathrm{r},}$ と $S$ との関係を図 11 に示す. $S$ 一定の下で $Q_{\text {sup }}(\psi)$ を減少 させると, $\mathrm{S}$ が小さな領域を除いて $Q_{\mathrm{r}}$ も $\psi=1$ に対する $Q_{\mathrm{r}}^{*}$ から減少していることが分かる. $S$ が小さい場合には, $Q_{\mathrm{r}}$ は $Q_{\mathrm{r}}^{*}$ よりも大きな值をとる場合も見られるが， $Q_{\text {sup }}$ の減少量の方が大きいため, 両者の和である $Q_{\text {in }}$ は減少し ている. 一方， $S$ が大きな場合には， $Q_{\text {sup }}$ の減少量自体がわずかであっても， $Q_{\mathrm{r}}$ は比較的大きく低下している. このため，S の計算領域全体にわたって， $Q_{\text {in }}$ はほぼ一定の割合で減少しており， $Q_{\text {in }}$ はフラッド潤滑における線 がほぼ平行に下側に移動していることが分かる.

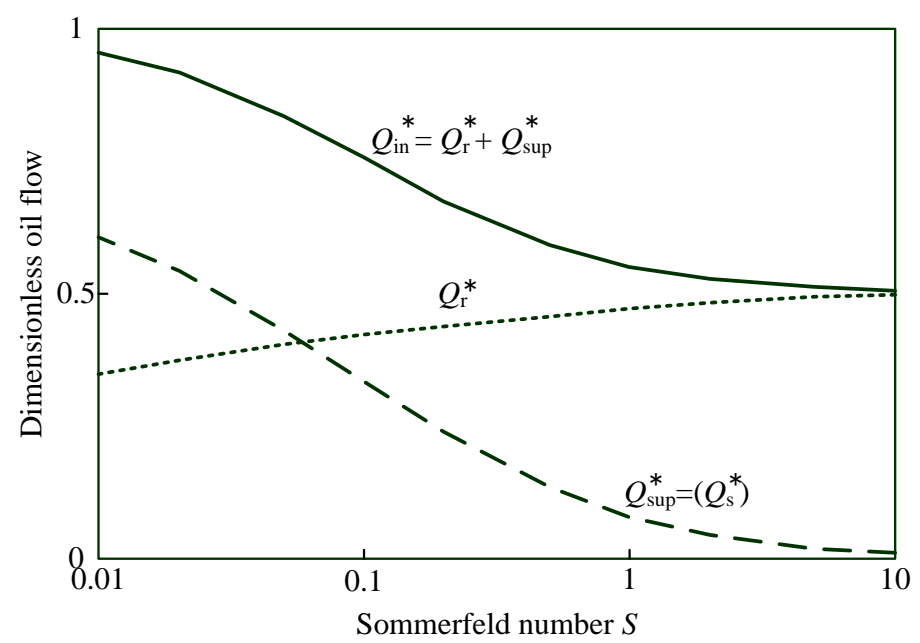

Fig. 10 Relationship between $Q_{\text {in }}, Q_{\mathrm{r}}$ and $Q_{\text {sup }}$ under flooded lubrication conditions $(L / D=1)$ 
図 12 に，図 11 で示した $Q_{\mathrm{in}}$ より計算される $\Lambda$ を示す. 若干の変動が見られるものの， $A$ は $S$ に対してはほぼ 一定の值になっている，これより，異なる運転条件，例えば回転速度が異なる二つの運転状態において給油量を 低下させる場合， $Q_{\text {sup }}$ のフラッド潤滑に対する割合が同じ，つまり $\psi$ を等しくすれば，結果として達成されるス

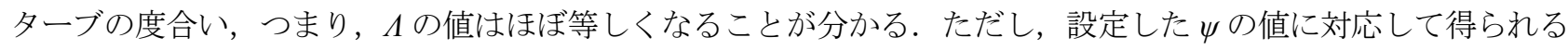
$\Lambda$ の值は異なっている. この原因は, 図 11 で見たように, $Q_{\text {sup }}$ と同じ割合で $Q_{\mathrm{r}}$ が減少しないためと考えられる.

表 2 に, $S=0.2$ における $\Lambda$ の值を示寸. $\psi=0.5$ で $\Lambda$ は約 $0.81, \psi=0.25$ で $\Lambda$ は 0.62 など, $\psi$ の減少量に比べて, $\Lambda$ の変化は小さいことが確認できる。これは, 給油量の削減量を誤って大きくした場合でも, スターブの度合い に与える影響は小さく抑さえられる，つまり，安全側に作用することを示唆している.

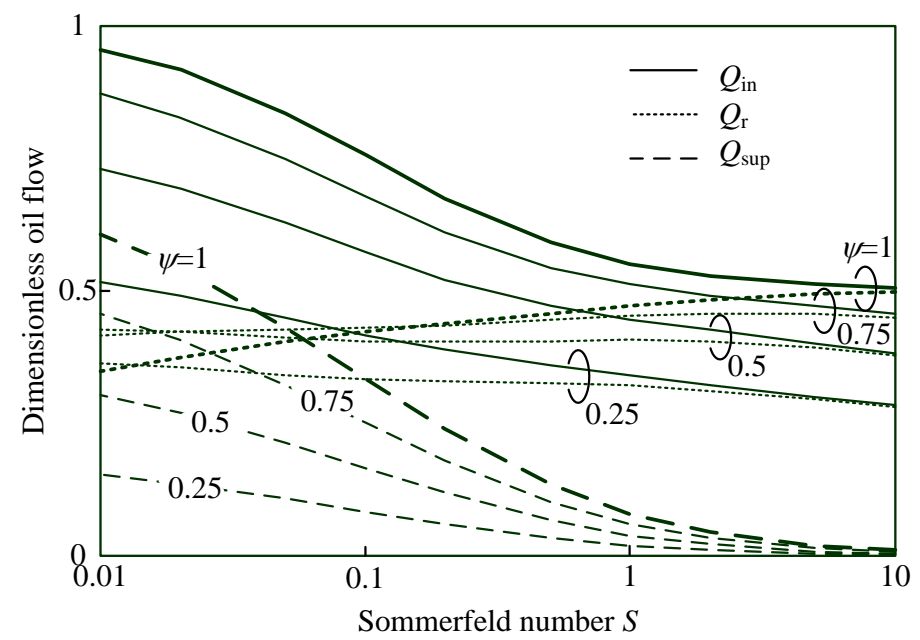

Fig. 11 Variations of $Q_{\mathrm{in}}, Q_{\mathrm{r}}$, and $Q_{\text {sup }}$ with Sommerfeld number for various oil supply rates $(L / D=1)$

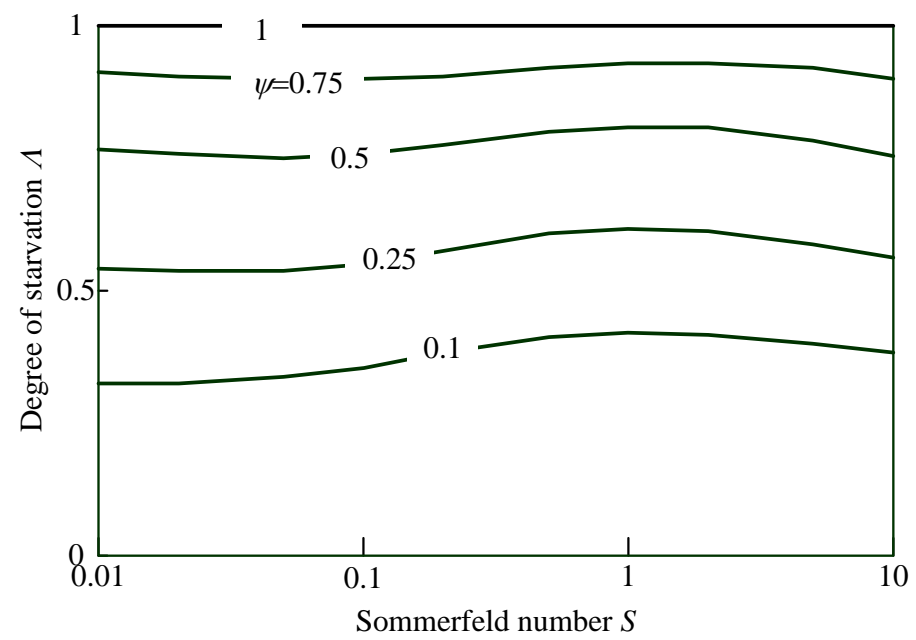

Fig. 12 Variations of degree of starvation with Sommerfeld number for various oil supply rates $(L / D=1)$

Table 2 Relationship between oil supply rate and degree of starvation $(S=0.2, L / D=1)$

\begin{tabular}{c|c}
\hline Oil supply rate $\psi$ & Degree of starvation $\Lambda$ \\
\hline 1 & 1 \\
\hline 0.75 & 0.93 \\
\hline 0.5 & 0.81 \\
\hline 0.25 & 0.62 \\
\hline 0.1 & 0.42 \\
\hline
\end{tabular}


以上の結果より， $\psi$ を指標にして給油量を変化させることにより，広い運転条件で $\Lambda$ の值を任意に設定できる ことが分かる.

\section{4. 結 語}

鉛直上方に軸方向油溝が一つ取り付けられた軸受幅径比（L/D）が 1 の真円ジャーナル軸受を対象に，ゾンマ 一フェルト数 $S$ および無次元給油量 $Q_{\text {sup }}$ の二つを変数として, フラッド潤滑とスターブ潤滑にまたがる幅広い運 転条件における軸受の静特性を調べた. 得られた結果を, 偏心率 $\varepsilon$ をパラメータとして横軸を $S$, 縦軸を $Q_{\text {sup }}$ で 表示する軸受状態図，ならびに $Q_{\text {sup }}$ をパラメータとした軸心軌跡を作成し，以下のことが明らかとなった.

1. 無次元給油量 $Q_{\text {sup }}$ の低下により偏心率 $\varepsilon$ は増加し, 偏心角は減少する. $Q_{\text {sup }}$ の低下が $\varepsilon$ の増加に及ぼす定 量的な影響は, ゾンマーフェルト数 $S$ が大きな場合ほど大きくなる.

2. フラッド潤滑状態を維持するために必要となる有次元の給油量 $q_{\text {sup }}$ は, 軸回転速度 $N$ により増加する. $q_{\text {sup }}$ を一定として $N$ を増加させていくと, ある回転速度以上でフラッド潤滑状態からスターブ潤滑状態に遷移 する. フラッド潤滑状態では $N$ の増加とともに $\varepsilon$ が一旦減少するが，スターブ潤滑状態に入ると， $N$ が増 加に対する $\varepsilon$ の減少する割合が小さくなり, さらに $\mathrm{N}$ の高い領域では $\mathrm{N}$ の増加に伴い $\varepsilon$ は増加する.

また，スターブの度合いを，軸受油膜前端に流入する無次元流量とフラッド潤滑時における值との比 $\Lambda$ で定義し，これと外部から供給する無次元給油量とフラッド潤滑時における值との比 $\psi$ の関係を調べた結 果，以下のことが明らかとなった。

3. $\Lambda$ は $\psi$ との相関があり， $\psi$ の増減に連動して $\Lambda$ の值が変化する. これより $S$ の広い範囲にわたって $\psi$ を一 定に保つことにより， をほぼ同じ值に維持できる.

\section{文献}

(1) D. Bonneau and J. Frene, "Film Formation and Flow Characteristics at the Inlet of a Starved Contact - Theoretical Study," Journal of Tribology, Vol. 105(1983), pp. 178-186.

(2) G. Bayada, "Variational Formulation and Associated Algorithm for the Starved Finite Journal Bearing," Journal of lubrication Technology, Vol. 105(1983), pp. 453-457.

(3) A. Artiles and H. Heshmat, "Analysis of Starved Journal Bearings Including Temperature and Cavitation Effects," Journal of Tribology, Vol. 107(1985), pp. 1-13.

(4) D. Vijayaraghavan, T.G. Keith, and D.E. Brewe, "Effect of Lubricant Supply Starvation on the Thermohydrodynamic Performance of a Journal Bearing," Tribology Transactions, Vol. 39(1996), pp. 645-653.

(5) H. Heshmat and O. Pinkus, "Performance of Starved Journal Bearings with Oil Ring Lubrication," Journal of Tribology, Vol. 107(1985), pp. 23-31.

(6) M. Tanaka, "Journal bearing performance under starved lubrication," Tribology International, Vol. 33(2000), pp. 259-264.

(7) H. Hashimoto and M. Ochiai, "Experimental Study on the Stabilization of Small-Bore Journal Bearings by Controlling Starved Lubrication and Bearing Orientation Angle," Journal of Tribology, Vol. 131(2009), p. 011705.

(8) H. Hashimoto and M. Ochiai, "Stabilization Method for Small-Bore Journal Bearings Utilizing Starved Lubrication," Journal of Tribology, Vol. 132(2010), p. 011703. 